rzyny Aleksandryjskiej, należącej również do łacinników, skąd codziennie odbywa się procesja do Groty Narodzenia. Do łacinników należy również leżąca w odległości 300 kroków od Groty Narodzenila tzw. G r o t a M l e c z n a wydrążona w białym kamieniu — tak zwana dlatego, bo według tradycji Matka Boża na tym miejscu karmiła swe Dziecię. Grota jest celem pielgrzymek, zwłaszcza niewiast bez różnicy wyznanila. Wspomnieć tu jeszcze należy o kościółku zwanym potocznie ,D o m e m ś w. J ó z e f a“, gdzie miała mieszkać św. Rodzina i o,P o l u P a s t e r z y“, leżącym na skraju miasteczka. Wszystkie te betlejemskie sanktuarila są obsługiwane i pozostają pod stałą opieką Franciszkańskiej Kustodii Ziemi Świętej.

...,Z $\mathrm{Z}$ okazji rocznicy szóstego stulecia, które obchodzimy, unoszą się jak najżywsze życzenia, aby jak najprędzej nowy duch pokoju i miłości snuł się nad Bazyliką i Grotą Narodzenia, już nie w rękach odszczepieńców, lecz w wyłącznym posiadaniu Kustodii synów świlętego Franciszka". - Tak kończy się słowo wstępu w wydanej z tej okazji wspaniałej księdze jubileuszowej, a zawierającej artykuły w wielu językach. O. Aurelemu Borkowskiemu należy się wdzięczność, że i o artykule w języku polskim pomyślał.

O. Augustyn Chadam, Bernardyn.

\title{
OSTATNIE CHWILE KS. JAKUBA WUJKA T. J.
}

Dnia 27-go lipca 1947 r. minęło 350 lat od śmierci ,polskiego Hieronima“, Jakuba Wujka z Wągrowca. Zasługi, położone około spolszczenia Pilsma św., zjednały mu ten zaszczytny tytuł. Ale należy mu się coś więcej: wdzięczna pamięć narodu. A to krótkie wspomnienie ma się przyczynić do jej utrwalenia.

W r. 1592 Ks. Wujek złożył urząd przełożonego domu św. Barbary w Krakowie, by z większą swobodą poświęcić się pracy nad przekładem Biblii. Mieszkał nadal w Krakowie, lecz wyjeżdżał do Warszawy i Poznania w sprawie drugiego wydania Nowego Testamentu i Psalterza. Kiledy w r. 1595 utworzono wiceprowincje siedmiogrodzką, przełożonym zamianowano K/s. Wujka, który także słynął jako Wielkopolanin $\mathrm{z}$ talentu organizatorskiego. 
Gorliwie zajął się nowymi obowiązkami i urządził odpowiednio domy $i^{1}$ kolegia jezuickie Siedmiogrodu, choć jeszcze nile ustała burza wojenna turecka. Pomimo tak licznych prac, udało mu się dokończyć w lipcu 1596 r. przekładu całej Biblii. Chciał teraz osobilście dopilnować jej wydania i w tym celu zjechał w r. 1597 do Polski, ale śmierć przecięła jego plany.

„Przestał żyć jednocześnie i pracować“ - mówi o Kș. Wujku Rostworowski, gdyż do końca życila nie wypuszczał z rąk pióra. W przeddzień swej śmierci wykończył jeszcze dedykację do dzieła: „Zywot i nauka Pana Naszego Jezusa Chrystusa“. Ks. Wujek zmarł 27 lipca 1597 r. w Krakowie w 57 roku życia, z których 32 spędził w Zakonie. Wczesną stosunkowo śmierć wywołało prawdopodobnie przemęczenie pracą, połączone z jakaśs chorobą ostatnilą, której nazwy i charakteru nie można określić dla braku wzmianek w źródłach.

Za przykładem św. Augustyna Ks. Wujek rozważał podczas ostatniej choroby psalmy pokutne. Na dzień przed zgonem przyjął ostatnie Sakramenta św. wśród wzruszających aktów ufności w Dobroć Bożą. Noc ostatnią strawił na modlitwie, wpatrzony w Chrystusa Ukrzyżowanego. Nad ranem, otoczony gronem zakonnych współbraci, spokojnlie zeszedł z tego świata, pozostawiając pamięć wybitnej świętości. Jeden $z$ obecnych wyraził się, że zmarłemu nie potrzeba już modlitw. Lecz później upomniany we śnie przez Ks. Wujka, cały rok żarliwie zań się modlił.

Cały Kraków z wielkim żalem i łzami żegnał swego duchowego przewodnika, biorąc tłumny udział w jego pogrzebie. Bardzo wielu. kapłanów przybyło $\mathrm{z}$ dalekich stron i odprawiało za nilego msze św. Uczestniczył w pogrzebie również Mikołaj Firlej, wojewoda lubelskï, składając hojne jałmużny w intencji zmarłego. Podistarości krakowski pragnął ujrzeć jeszcze nieboszczyka przed samym złożeniem. do grobu. Kiedy otwarto trumnę, zalał się rzewnymi łzami. Kustosz Bernardynów stradiomskich, Ambroży z Mogilna, sławiąc w mowie pogrzebowej cnoty it czyny zmarłego, wołał z żalem: „Upadł jeden fillar Kościoła Bożego".

Pogrzebamo go w kościele św. Barbary pod mniejszym rzędem ławek mężczyzn. Po kilku latach zebrano kości do innej trumienki, którą złożona pod wielkim ołtarzem. W r. 1886 O. Załęski, w latach 1908 i 1936 ówcześni Przełożeni domu poszukiwalił prochów Ks. Wujka, lecz wszystkie starania spelzły na niczym; śladu trumny nie 
znaleziono. Zdaje się spełniać starożytna tradycja zakonna, według której Ks. Wujek miał się modlić, by po nilm po śmierci nic nie pozostało. Nawet bezpośrednio po śmierci niczego po nim nie znaleziono, krom koronki i skromnego relikwiarza.

Generał Zakonu Klaudlusz Akwawiwa pozwolił na umieszczenie wspomnienia o Ks. Wujku, jak i o Skardze w menologium całego Zakonu, co jest rzadkim wyróżnieniem.

Znajdują się świadectwa, które dokładnie cytuje Sygański w Przeglądzie Powsz. 1914 r., opowiadające o zachowaniu nileskazitelnym ręki Wujka, mimo, że całe ciało w proch się rozpadło. Zbija je jednak Wielewiecki, który pod tym względem jest najbardziej miarodajnym. Znał bowilem wszystkie relacje i diariusze, związane z rzekomym faktem, a o których milczą sprawozdania dokładne Sawickiego i Skargi, obecnych w tym czasie na miejscu wykrycia cudownej ręki. Niedbalstwo zaś Jezultów w zachowaniu owej rękí, gdyby ją znaleziono, jest mniej, niż prawdopodobne. Dlatego opowiadanie to uważać trzeba za legendę.

Rodacy Wujka, mieszkańcy Wągrowca, pod Poznaniem, wystawili mu w r. 1931 z inicjatywy proboszcza Ks. Wróblewskiego przed kościołem marmurowy pomnik z pięknie wykonanym przez artystę Haupta popiersiem (według starego sztychu). Niestety niemcy w czasie okupacji pomnik ten zniszczyli.

Ubolewać należy — pisał w r. 1917 Ks. Sygański - że w Krakowie, gdzie spoczywają jego śmjertelne szczątki, dotychczas nie ma żadnego, choćby skrcmnego epitaphium, na które dobrze sobie zasłużył. Słowa te mają się obecnie doczekać realizacji, albowiem Wydział Teologiczny Uniwersytetu Jag. postanowił w październiku 1949 r. - na pamiątkę 350-lecia wydania Biblii Wujkowej — zwołać zjazd biblistów polskich i w porozumbeniu z O. Prowincjałem Ks. Ks. Jezuitów przygotować wmurowanie tablicy pamiątkowej na kościele św. Barbary. Równocześnie zamierza Wydział wydać osobny zeszyt „Polonia Sacra“, poświęcony Ks. Wujkowi.

L i t e r a t u a: Wielewiecki, Dziennk spraw domu św. Barbary, Scriptores Rer. Pol.. t. VII, 237-240; t. X, str. 66. Sygański, Korespondenoja Ks. Wujka z lat 1569-96, Poznań 1917. Tenże: Wujek w świetle korespondenoji, Przegląd Powsz. 1914 r. Załęski: Jezuici w Polsce, t. I, 710-717, Lwów 1900. Pamiętnik religijnomoralny, t. VI, r. 1844, str. 208. Rostowski: Lithuanicarum S. J. Histor, Parisiis 1877 , str. $186 \mathrm{n}$.

Ks. Edward Haratym T. J. 